\title{
Thinking and Reforms of Plant Biotechnology Course Teaching in Agricultural Professional Master Cultivation
}

\author{
Yihong Hu *, Wenshuai Zeng, Chenzhong Jin, Yong Chen, Xuejiao Zhang, Yan Wang \\ Key Laboratory of Harmless Application of Pesticide in Hunan Higher Education \\ Hunan University of Humanities, Science and Technology \\ Loudi 417000, Hunan, China \\ huyhongwangyi@163.com
}

\begin{abstract}
To promote the professional skills and quality developments of the agricultural professional postgraduate students in the agronomy and seed industry specialty and the resources use and plant protection specialty, plant biotechnology were selected as a backbone course or selective course and the teaching reforms were performed in Hunan University of Humanities, Science and Technology. This paper introduced the characteristic personnel training mode in the university, analyzed the status of plant biotechnology in the course system, put forward the questions found during teaching of this course, and introduced the past years practice and reforms. As a result, a teaching group for this course was set up, the teaching mode was renewed, and the teaching contents were enriched to keep pace with times. Through eight years practice, the teaching effect of this course was evidently improved. The practice and experiences will be valuable for the other universities and scientific institutions.
\end{abstract}

Keywords-plant biotechnology; agricultural professional postgraduate students; personnel train mode; teaching effect; reforms

\section{INTRODUCTION}

Hunan University of Humanities, Science and Technology acquired the pilot authorization for cultivation of the agricultural extension masters in 2011 which was to serve the special needs of the country. In 2012, the university began to recruit the full-time postgraduate students for the professional master's degree, and four specialties had been set up since then, including the crop specialty, the plant protection specialty, the rural areas and development specialty, and the agricultural information specialty. Among them, the plant biotechnology course was the main backbone course for the crop specialty and the selective course for the plant protection specialty in order to promote the professional skills and quality developments of the students. In 2014, the agricultural extension master was renamed to the agricultural master, the former 15 specialties were integrated into eight specialties, and the former crop specialty and the plant protection specialty were enriched and renamed as the agronomy and seed industry specialty and the resources use and plant protection specialty (Table I). Since the specialties were adjusted, the status of the plant biotechnology

This research was financially supported by Innovation Base for Postgraduates Cultivation of Hunan Province (2261602) and Research Project of Teaching Reform of Degree and Graduate Education in Hunan (JG2016B106) course has been changed a little. According to the national guidance cultivation plans put forward by the National Steering Committee of Agricultural Graduate Education of Agricultural Professional Master, the plant biotechnology course was still chosen as the selective course both for the agronomy and seed industry specialty and for the resources use and plant protection specialty in our university.

TABLE I. SPECIALTIES INTEGRATIONS OF AgRicUltural MASTER AFTER 2014

\begin{tabular}{|c|l|l|}
\hline Year & \multicolumn{2}{|c|}{ Specialty name } \\
\hline \multirow{3}{*}{$\begin{array}{c}\text { Before } \\
2014\end{array}$} & Crop & Agricultural resources use \\
\cline { 2 - 3 } & Horticulture & Plant protection \\
\cline { 2 - 3 } & Prataculture & \\
\cline { 2 - 3 } & Forestry & $\begin{array}{l}\text { Resources use and plant } \\
\text { protection }\end{array}$ \\
\hline
\end{tabular}

As we all know, the biotechnology is developing rapidly, and more and more new biotechnologies such as genetics engineering, enzyme engineering, cell engineering and fermentation engineering which are being used in the agricultural areas day by day [1-4]. Since plant biotechnology is a very important course for the agricultural professional postgraduate students, the students should master the up-todate technologies relative to these areas. During the past eight years, we have paid much attention on this course in the cultivation of the agricultural professional postgraduate students in the agronomy and seed industry specialty and the resources use and plant protection specialty, and a lot of excellent teaching effects have been achieved. This paper has summed up the common problems encountered during the course teaching, retrospect's our past years' thinking and work in the course teaching, and introduced the practice and experiences in order to provide a helpful reference for the other universities and scientific institutions.

\section{ANALYSIS ON STATUS OF PlANT BiOTECHNOLOGY COURSE}

\section{A. Course system}

The course system for agricultural master in our university was designed to meet the occupational demands, pay attention to the combination of humanities and technology, and 
emphasize on promoting the comprehensive quality and professional knowledge as the core of education. For these purposes, the full curriculum was divided into four modules including the public degree courses, the backbone courses, the professional skills course, and the professional development courses (Table II). According to the guidance plan of the National Steering Committee of Agricultural Graduate Education of Agricultural Professional Master and the real needs from the society for the agricultural professional master's postgraduate students, the plant biotechnology course was arranged as a backbone course or a professional skills course for the crop specialty and the plant protection specialty before 2014. After the combination of specialties in 2014, the two new specialties, which were the agronomy and seed industry specialty and the resources use and plant protection specialty, were emphasizing on the areas of crop, horticulture, seed industry, and plant protection. Therefore, the biotechnology course was retained as a selective course for professional skills training in the current teaching schedule.

TABLE II. Four MOdUlES OF COURSES IN AGRICULTURAL PROFESSIONAL DEgREE EDUCATION

\begin{tabular}{|c|c|c|}
\hline Module & Course description & $\begin{array}{c}\text { Course } \\
\text { type }\end{array}$ \\
\hline Public degree courses & $\begin{array}{l}\text { Following the guidance } \\
\text { plan of the National } \\
\text { Steering Committee of } \\
\text { Agricultural Graduate } \\
\text { Education of Agricultural } \\
\text { Professional Master }\end{array}$ & $\begin{array}{l}\text { Required } \\
\text { courses }\end{array}$ \\
\hline Backbone courses & $\begin{array}{l}\text { Following the guidance } \\
\text { plan of the National } \\
\text { Steering Committee of } \\
\text { Agricultural Graduate } \\
\text { Education of Agricultural } \\
\text { Professional Master }\end{array}$ & $\begin{array}{l}\text { Required } \\
\text { courses }\end{array}$ \\
\hline $\begin{array}{l}\text { Professional skills } \\
\text { courses }\end{array}$ & $\begin{array}{l}\text { Designing practical } \\
\text { application-oriented } \\
\text { courses for agricultural } \\
\text { industry according to } \\
\text { professional orientation }\end{array}$ & $\begin{array}{l}\text { Selective } \\
\text { courses }\end{array}$ \\
\hline $\begin{array}{l}\text { Professional development } \\
\text { courses }\end{array}$ & $\begin{array}{l}\text { Concerning } \\
\text { entrepreneurship } \\
\text { management, public } \\
\text { relations etiquette, } \\
\text { document writing, and } \\
\text { agricultural project } \\
\text { management and } \\
\text { evaluation }\end{array}$ & $\begin{array}{l}\text { Selective } \\
\text { courses }\end{array}$ \\
\hline
\end{tabular}

\section{B. Sequence of plant biotechnology course in terms}

The personnel training mode for the agricultural professional masters in our university is called "three doubles, four modules, and seven terms" (Fig. 1.), and the basic schooling length was 2.5 years. In this mode, the "three doubles" included double cultivation subjects such as university with enterprises and off-campus tutors with oncampus tutors, and double terms such as theoretical study terms and practice terms which were alternated; and the total number of terms amounted to seven. Guided by the personnel training mode, the plant biotechnology course were offered on the fifth term after the postgraduate students experienced the cognitive practice on the first term, the theoretical study on the second and the third terms, and the curriculum practice on the forth term when they had acquired enough theoretical knowledge and practical experiences in the agricultural area.

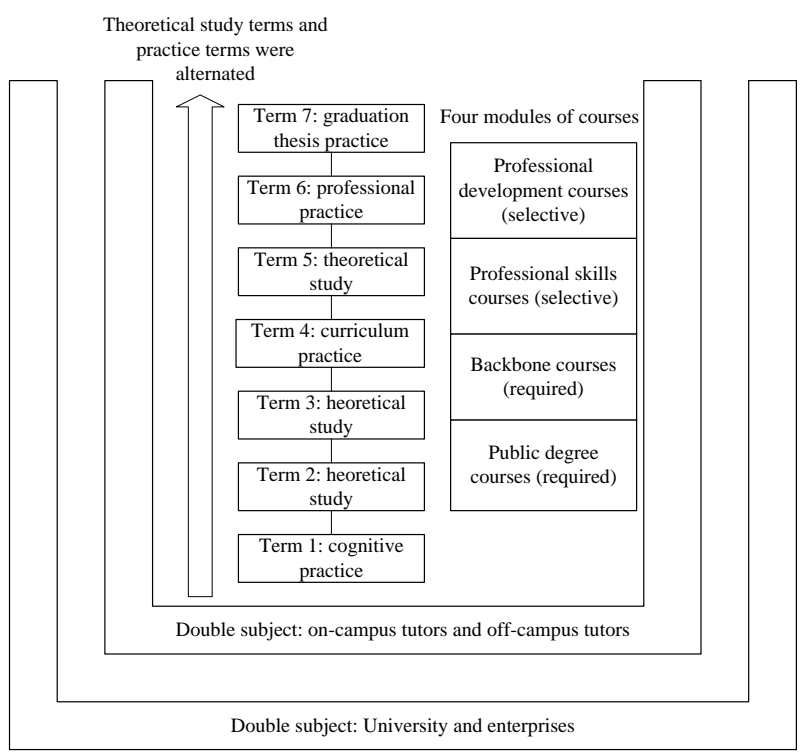

Fig. 1. Personnel training mode for the agricultural professional masters

\section{PROBlems Found DURING TEACHING PLANT BIOTECHNOLOGY}

\section{A. Pertinence of teaching contents was not strong}

Biotechnology covers a wide range of applications on many disciplines including the plant science, animal science, the bioengineering, and even the medical science etc. [5-7]. As for postgraduate students in the agronomy and seed industry specialty and the resources use and plant protection specialty, the teaching contents should mainly focus on the new applications of technologies in genetics and bio-engineering in order to improve the agricultural production in future. For example, the new applications of biotechnology in male sterility breeding and the cultivation of resistant plant varieties should be introduced in this course, whereas the basic knowledge about biochemistry and biomolecule technologies should be deleted because most of the students had studied the basic knowledge during their undergraduate stage. Although these new parts of knowledge were practical and essential to the students, they were often new to some teachers. In reality, the teachers were more willing to pass on their familiar knowledge to students, and they trended to teach the traditional contents.

\section{B. Lack of suitable teaching materials}

Owing to the wide coverage of biotechnology and the characteristic needs for cultivation of agricultural professional postgraduate students, it was difficult to find suitable teaching materials for the postgraduate students in our university. At the very beginning, we selected several national planned authoritative textbooks such as the third edition of "Introduction to biotechnology" (published by Science Press, China), the second edition of "Plant biology" (published by High Education Press, China), and "Plant biotechnology" 
(published by Science Press, China). These textbooks were authoritative and rich in content, and the authors are all experts in the biotechnology industry, but soon the abuse emerged. These textbooks were not suitable for the postgraduate students in the crop specialty and the plant protection specialty in the local university and many parts of these textbooks could not be effectively used during teaching. To overcome these difficulties, the lecture notes were compiled for teaching and the teaching effect was improved.

\section{Teaching cases were out of touch with practical needs}

The teaching process of plant biotechnology was designed with several styles including the theory lecture, the experiment teaching, the case teaching, and the discussion in class. For example, in enzyme engineering teaching of the plant biotechnology course, the purification and fixation of the enzyme oxalate oxidase (E.C. 1.2.3.4), which is an enzyme to degrade oxalate into hydrogen peroxide and carbon dioxide [8], was often applied as a classical teaching case. On the contrary, this case was not put into use in the agricultural industry in reality. The fact was that there were some cases which were more suitable for teaching such as the fixation of enzyme to degrade the pesticides in soils, and the extraction and preparation of heavy metal degradation enzymes from bacteria and so on.

\section{Teaching contents were not closely connected with international trend of agricultural development}

In some of the developed countries, agriculture has already become a highly intensive industry, and biotechnology is now widely used in the scale agricultural production [9-10]. As for postgraduate students in agriculture, they should keep a close eye on the international trend of agricultural development, and the teachers should introduce the latest biotechnologies used in the scale agricultural production from the developed countries such as biotechnological applications in breeding, weeding, and farming etc.

\section{PRACTICE AND REFORMS}

\section{A. Forming a teaching group for plant biotechnology course}

Since plant biotechnology is developing rapidly, and the new methods and technologies are being applied in the agricultural industry day by day, it is very difficult for a single teacher to carry on the whole course of plant biotechnology from the beginning to end with an ideal teaching effect. In view of this, a course group was set up in our university to teach including several teachers whose specialty backgrounds were genetics, plant molecular biology, fermentation engineering, enzyme engineering, and bioinformatics etc. Most of them owned a Ph.D title and some of them used to study overseas as visiting scholars. Each teacher taught a part of the course which was quite familiar to him to ensure an ideal teaching effect. The teaching group was established in 2012, the teachers actively participated in teaching, the response from the teachers was positive, and this method of group teaching was also welcome by the postgraduate students.

\section{B. Compiling textbook for plant biotechnology course}

Because there were no suitable textbook of plant biotechnology for the agricultural professional postgraduate students, the lecture notes were compiled for teaching at the beginning. The characteristic of lecture notes was that their contents could be changed and increased flexibly according to the teaching needs, but the defects were also obvious. The lecture notes were not reviewed by the industry experts and not edited by the professional editors, so that there were errors, insufficiencies, and even omissions unavoidably in them, and they did not conform to the standardization requirement of teaching. With the accumulating experiences of compiling lecture notes, a textbook were published finally, i.e. "Agricultural biotechnology tutorial", published by the Southwest Jiaotong University Press in 2015 for the plant biotechnology teaching. Subsequently, a series of relevant teaching materials were published thereafter. In this textbook, the main modern bioengineering methods and applications of biotechnology were introduced. At the end of each chapter, a case was added for students to understand the biological principles more deeply. And the edition was planned to revise at least every five years in order to update the contents.

\section{Introducing various teaching methods in course teaching}

The teaching hours of the plant biotechnology course were set to 32 periods in total in our university, the teaching methods were including theory teaching, lecture, discussion, and students oral reports, and the opening inter-active teaching hours accounted for at least one half of the total teaching hours. The teachers put forward some topics with no definite answers in class for students to debate or discuss, and then they induced the students to form their own conclusions step by step. For example, the teachers firstly raised some questions like "can seed-coating agents be used in rice", "can enzyme fixation technology be used in agricultural production", "will chemical pesticides be replaced by bio-pesticides in the future", "how about the development trend of the production of organic foods in China" or some other questions like those for students to debate, and then the teachers implicitly guided the students to discuss and finally reflect the nature of plant biotechnology during the discussion in order to form their own conclusions by students themselves.

\section{Keeping teaching contents with pace of times}

The key teaching point was adjusted according to the needs of the agricultural personnel markets. In Hunan Province of China, rice is a main leading agriculture industry. Thus, the application of biotechnology in hybrid rice seeds processing was chosen as an important teaching point for postgraduate students in the agronomy and seed industry specialty. As for postgraduate students in the resources use and plant protection specialty, considering the increasingly stringent environmental requirements, the application of biotechnology in the biogenic pesticides production was chosen as the key point to teach. For example, the extraction and production of botanical pesticides and botanical protective agents against the chemical pesticides were chosen as the hot topics in teaching. And the teachers also put their latest scientific findings into their lectures. Meantime, a bulk of new resources on the internet websites including 
"http://www.ncbi.nlm.nih.gov", "http://www.bio1000.com”, "http://www.zgny.com.cn",

"http://www.biotech.org.cn", "http://www.sciencenet.cn", "http://www.zb89.com", "http://wssa.net”, "http://www.zhiwutong.com" and so on (Table III), were used to enrich the teaching materials in order to keep the teaching contents tightly with the pace of times.

TABLE III. WEBSITES ON INTERNET AVAILABLE

\begin{tabular}{|c|l|l|}
\hline No. & \multicolumn{1}{|c|}{ Website } & \multicolumn{1}{|c|}{ Description } \\
\hline 1 & http://www.ncbi.nlm.nih.gov & $\begin{array}{l}\text { Website of the National } \\
\text { Center for Biotechnology } \\
\text { information of the United } \\
\text { States }\end{array}$ \\
\hline 2 & http://www.biotech.org.cn & $\begin{array}{l}\text { Website of China } \\
\text { biotechnology information }\end{array}$ \\
\hline 3 & http://www.bio1000.com & Web portal site of bioscience \\
\hline 4 & http://www.sciencenet.cn & $\begin{array}{l}\text { Science website sponsored } \\
\text { by Chinese Academy of } \\
\text { Science }\end{array}$ \\
\hline 5 & http://www.zgny.com.cn & Chinese agricultural website \\
\hline 6 & http://www.zb89.com & $\begin{array}{l}\text { Web portal site of plant } \\
\text { protection }\end{array}$ \\
\hline 7 & http://wssa.net & $\begin{array}{l}\text { Website of Weed Science } \\
\text { Society of America }\end{array}$ \\
\hline 8 & http://www.zhiwutong.com & Website of plant science \\
\hline 9 & http://www.cncbd.org.cn & $\begin{array}{l}\text { Website of China National } \\
\text { Center for Biotechnology } \\
\text { Development }\end{array}$ \\
\hline 10 & http://www.csab.net.cn & $\begin{array}{l}\text { Website of Chinese Society } \\
\text { of Agri-Biotechnology }\end{array}$ \\
\hline
\end{tabular}

\section{E. Putting teaching contents in line with agricultural} production

The plant biotechnology has been developing rapidly and applied widely in the agricultural industry in the recent years. For example, there are two main areas which are heavily involved with biotechnology in agriculture production: one is the quick development of resistances of weeds to herbicide, and the other is the molecular mark assisted breeding. In these areas, biotechnology has become a common and necessary tool both in the agricultural researches and the scale production. In order to make the teaching contents of the plant biotechnology course closer to the agricultural practice, some of these examples were gathered as teaching materials to enrich the course.

\section{SUMMARY}

The plant biotechnology course is an important course for agricultural professional postgraduate students in the agronomy and seed industry specialty and the resources use and plant protection specialty. After our university acquired the pilot qualification for the cultivation of agricultural master's postgraduate students, a characteristic personnel training mode was established and reforms on the plant biotechnology course teaching were made such as setting up a teaching group, renewing the teaching mode, and enriching the teaching contents. Through eight years practice, the teaching effect was evidently improved.

\section{REFERENCES}

[1] Y. Liu, Y. Guo, and H. Cai, "Analyses and advices on the industry of agricultural biological inputs in Beijing," Tianjin Agricultural Sciences, vol. 23, pp. 41-45, 2017. (In Chinese)

[2] L. Liang, Z. Wang, and J. Duan, "Practice and thinking of diversified teaching reform in enzyme engineering under the background of "Internet+," Mircrobiology China, vol. 45, pp. 2285-2292, 2018. (In Chinese)

[3] Z. Qiu, “Application of cell engineering technology,” Biological Chemical Engineering, vol. 4, pp. 140-143, 2018. (In Chinese)

[4] S. Wang, "Study on the countermeasures of agriculture and biological industry in Liaoning,” Journal of Mudanjiang University, vol. 27, pp. 16-19, 2018. (In Chinese)

[5] D. Zhao, H. Xie, and Q. Li, "Characterized biotechnology and bioengineering - also discussed the difference between the bioengineering and biomedical engineering,” Journal of Biology, vol. 34, pp. 113-118, 125, 2017. (In Chinese)

[6] X. Jing, "Application prospect analysis of biotechnology,” Biological Chemical Engineering, vol. 4, pp. 124-126, 2018. (In Chinese)

[7] D. Chen, Y. Wang, R. Pu, Y. Ao, and Y. Sun, "The era of biotechnology: new laws, new developments and new paths," Chinese Bulletin of Life Sciences, vol. 30, pp. 891-895, 2018. (In Chinese)

[8] H. Rana, P. Moussatche, L. S. Rocha, S. Abdellaoui, S. D. Minteer, and E. W. Moomaw, "Isothermal titration calorimetry uncovers substrate promiscuity of bicupin oxalate oxidase from Ceriporiopsis subvermispora," Biochemistry and Biophysics Reports, vol. 5, pp. 396400, 2016.

[9] T. Liu, "Implementation and management system of agricultural science and technology promotion in Israel and its enlightenment,” Journal of Shanxi Agricultural University (Social Science Edition), vol. 17, pp. 3945, 2018. (In Chinese)

[10] X. Li, J. Huo, H. Zhang, B. Qu, and F. You, "Experience and enlightenment of agricultural resource management in the United States,” Chinese Journal of Agricultural Resources and Regional Planning, vol. 39, pp. 86-90, 2018. (In Chinese) 